\title{
Die Paasfeesviering van die Henogitiese Quartadecimane in die eerste drie eeue van die Christendom
}

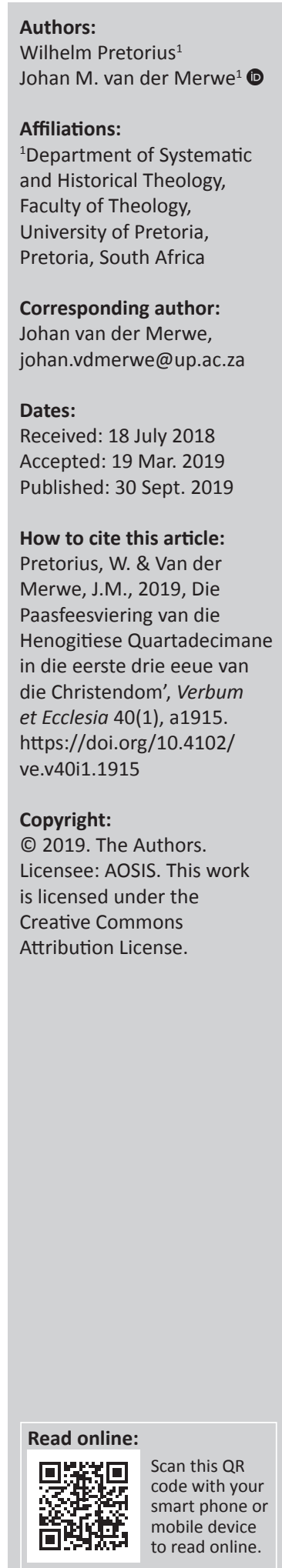

The celebration of the Passover of the Enoochite Quatradecimans during the first three centuries of Christianity. Development concerning the determination of Passover or Pascha's annual date took place during the first three centuries of Christianity. This led to a controversy in the mid-second century AD which became known as the Quartadecima Controversy. The date and duration of the Passover were the main issues. During the controversy two main streams emerged, namely theQuartadecimans and Anti-Quartadecimans. TheQuartadecimans celebrated the 14th of the first month annually as the commencement date of the Passover. The Anti-Quartadecimans set the first or second weekend after the 14th of the first month annually as the Passover celebration date. In spite of the two main streams, commonly accepted by modern-day researchers, various variations developed within these two main streams. These variations have not been discerned and analysed in modern-day research. One of these variations, namely the Enochite Quatradecimans is the subject of this article. They are being portrayed as a unique and discernable variation within the Quartadeciman main stream.

Intradisciplinary and/or interdisciplinary implications: This article connects the research fields of New Testament and Church History in trying to understand how and when the Passover was celebrated during the first three centuries of Christianity.

Keywords: Passover; Quartadecimans; Quartadecima Controversy; Enochites, Christianity; first three centuries.

\section{Inleiding}

In die eerste eeu ná die evangeliese tyd tot ongeveer die helfte van die 2 de eeu n.C., het Christene elkeen in eie gemeentes voortgegaan om 'n tradisie uit te leef ten opsigte van die tyd en wyse waarop hulle die Paasfees gevier het. Dit sluit die bepaling in van die Paasfees se begin, asook die duur van die fees. Die stelselmatige erkenning en bewuswording van die verskille het aanleiding gegee tot die ontwikkeling van 'n vraagstuk, genaamd die Quartadecima-vraagstuk. Quartadecima is 'n Latynse term wat vertaal kan word as: 14de, na aanleiding van die $14 \mathrm{de}$ Abib wat in die Ou Testament as begindatum van die Paasfees verorden is. ${ }^{1}$ Die twee strome wat algemeen in hierdie vraagstuk erken word, is die Quartadecimane en Anti-Quartadecimane. Eersgenoemde het die Paasfees jaarliks op 14 Abib begin vier en laasgenoemde op die Vrydag direk voor die eerste (of sommige die tweede) Sondag ná 14 Abib. Die Quartadecima-vraagstuk het in drie fases afgespeel tot aan die einde van die 2de eeu n.C. Tog het die kontroversie nie heeltemal verdwyn nie sodat verskeie kerkvaders gedurende die 3de eeu n.C. steeds hierdie onderwerp besoek het en daaroor ' $n$ eie opinie gevorm en op ander skrywes gereageer het.

In die navorser se proefskrif is gevind dat te midde van die twee strome, naamlik die Quartadecimane en Anti-Quartadecimane, daar verskeie variasies ontwikkel het waarin elkeen die Paasfees op 'n unieke wyse met eiesoortige kalendriese bepalings rakende die Paasfees gevier het.

In hierdie artikel word gefokus op een van hierdie variasies, naamlik die Henogitiese Quartadecimane. Die doel van die artikel is dus om die Henogitiese Quartadecimane te identifiseer en te ontleed soos wat hulle in die eerste drie eeue van die Christendom voorgekom het.

1.Eksodus 12:6, 18; Levitikus 23:5; Numeri 9:3, 5; 28:16; Josua 5:10; 2 Kronieke 30; 35:1; Esra 6:19; Ester 45:21. 


\section{Etiese oorwegings}

Hierdie artikel volg alle etiese standaarde vir navorsing sonder direkte kontak met mens of dier.

\section{Begrondingsbasis van die variante Paasfeesgebruike}

Die onderskeie variasies van Paasfeesgebruike het eerstens van mekaar verskil op grond van hulle etiologiese en mimetiese begrondinge. Etiologiese begronding beteken dat hulle die Paasfees op 'n spesifieke wyse liturgies vertolk het deur middel van liturgiese handelinge in navolging van hoe dit in hulle bron, waarop hulle dit begrond, liturgies nagevolg en uiteengesit is. Hulle vier byvoorbeeld die Pasga op 14 Abib omdat dit volgens Eksodus se beskrywing op daardie dag moet begin. Dit is dus etiologiese begronding op die wet.

Mimetiese begronding behels die liturgiese handelinge wat begrond is op 'n historiese narratief, gebeurlikheid, metafisiese of abstrakte onderwerp sodat dit in die liturgiese handeling vertolk en herdenk word. Die Sondagviering is dus mimeties op die opstanding van Jesus begrond as herdenking en uitdrukking van die opstandingnarratief.

Daar was twee basisse waarop die Paasfeesviering binne hierdie drie eeue n.C. etiologies en mimeties begrond is, naamlik die Ou Testament en die Nuwe Testament. In die Ou Testament is dit grootliks op die wet begrond. In die Nuwe Testament is dit hoofsaaklik op die kruisiginggebeure begrond.

Midde die kruisiginggebeure was daar vier begrondingselemente, naamlik:

- Die Pasgamaal van Jesus en sy dissipels. ${ }^{2}$

- Jesus se kruisiging op die tyd wat die Pasgalam geslag is. ${ }^{3}$

- Die Pasga wat ná Jesus se kruisiging plaasgevind het. ${ }^{4}$

- Die opstanding van Jesus op die eerste dag van die week. ${ }^{5}$

Variante vierings van die Paasfees het in die eerste drie eeue ontstaan na aanleiding van 'n variant se begronding en die klem wat op een van hierdie vier begrondingselemente geplaas is, op die tydsintervalle wat tussen die elemente voorgekom het en hoe die variant die element liturgies vertolk het (Stewart-Sykes 1998:154-155).

\section{Henogitiese Quartadecimane se liturgiese begronding}

Die stroom wat behandel gaan word, is die Quartadecimane. Die gemeenskaplike eienskappe wat die Quartadecimane gedeel het, was dat hulle die Paasfees jaarliks op 14 Abib begin vier het (Rudolph 2004:1). In hierdie artikel is die

2.Matteus 26:17-30; Markus 14:12-26; Lukas 22:7-23.

3.Josua 19:14; Markus 15:25; 33; Matteus 27:45; Lukas 23:44; 1 Korinthiërs 5:7.

4.Josua 18:28; 19:14; Markus 14:1-2.

5.Matteus 28:1; Markus 16:2, 9; Lukas 24:1; Josua 20:1; Petrus Evangelie 9-11 (35-49).
Henogitiese Quartadecimane die groep waarna gekyk gaan word wat as variant binne die Quartadecimane bestaan het.

Die Henogitiese Quartadecimane het eerstens hulle Paasfeesviering hoofsaaklik etiologies op die $\mathrm{Ou}$ Testamentiese geskrifte begrond. Dit behels geskrifte wat vandag as kanonieke sowel as nie-kanonieke beskou word. Tweedens op die wyse waarop Jesus die Paasfees gevier het, soos in die kruisigingsgebeure beskryf is. Hulle het dit wel ook mimeties op die kruisigingsgebeure begrond, maar dit wil voorkom of dit nie so belangrik was soos die etiologiese begronding nie (Richardson 1973:80; StewartSykes 1998:152).

\section{Henogitiese Quartadecimane se etiologiese begronding op die Ou Testament}

In die Ou Testament word die Paasfees op 14 Abib bepaal. ${ }^{6}$ Dit word as 'n bepaalde tyd (מועד) beskou, wat 'n feestelike karakter het as 'n heilige en gewyde fees (Levine 1989: Lv. 23:4; Strong 1997:3259; Swanson 1997:4595). Die lam moet teen die aand (ad vesperem) van 14 Abib geslag word $^{7}$ en daarna tydens die aand van 14 Abib geëet word. ${ }^{8}$ Ná die Pasga-aand volg die Fees van die Ongesuurde Brode. Die fees het vir 7 dae van 15 tot 21 Abib geduur, waartydens ongesuurde brode geëet is. ${ }^{9}$ Die eerste en sewende dag van die Fees van die Ongesuurde Brode was gewyde dae, wat die karakter van 'n Sabbat veronderstel. ${ }^{10}$ Die Pasga-aand en die Fees van die Ongesuurde Brode was twee onderskeie feeste wat deel gevorm het van die Agtdaagse Fees, wat ook die Paasfees, Pasga of Fees van die Ongesuurde Brode genoem word. ${ }^{11}$

In die tydperk van die Hasmoniese dinastie tot en met die vernietiging van die tempel in 70 n.C. het daar twee prominente strome in Judaïsme ontwikkel, naamlik die Henogitiese en die Hasmonitiese strome (Boccaccini 1998:113, 129-130; Pretorius 2006:272-294, 2008:34-38). Een van die belangrikste verskille tussen die twee groepe is die kalenders wat hulle gebruik het (Baumgarten 1995:31 e.v.; Glessmer 1999:221; Stemberger 1991; Talmon [1951] 1989:147-149; Talmon, Ben-Dov \& Glessmer 2001:xi). Die Hasmonitiese Judaïsme, verteenwoordig deur die Fariseërs en Sadduseërs, het die Babiloniese son-maankalender gevolg. Hierdie kalender was ingedeel van aand tot aand, die maande het uit onderskeidelik 29 en 30 dae bestaan en die jaar uit 354 dae. Die jaar was ongeveer 11 dae korter as die sonjaar sodat ongeveer elke derde jaar ' $n$ interkalasie- of ekstra maand 6. Ekodus 12:6, 18; Levitikus 23:5; Numeri 9:3, 5; 28:16; Josua 5:10; 2 Kronieke 30; 35:1; Esra 6:19; Ester 45:21

7.Eksodus 12:6, 18; Levitikus 23:5; Numeri 9:3, 5; 33:3; Deuteronomium 16:1-6; Beckwith 2001:1.

8.Eksodus 12:8; Numeri 28:16; Deuteronomium 16:1, 4; Josua 5:10; Esra 6:19; Ester 40:1-48:35.

9.Eksodus 12:15-19; 13:6; 23:15; 34:18; Levitikus 23:5; Numeri 28:17; Deuteronomium 16:1-8; 2 Kronieke 30:21-23; 25:17; Esra 6:19; Ester 45:21.

10.Eksodus $12: 16 ; 13: 6$; Levitikus 23:7-8.

11.Eksodus 12:11, 34; Levitikus 23:5; Numeri 9:2, 4-6, 10, 12-14; 28:16; 33:3; Deuteronomium 16:2-3, 5-6; 2 Kronieke 30:13-15, 18-21. 
ingevoeg is ten einde hulle kalender in sinkronisasie met die sonkalender te bring. ${ }^{12}$

Teenoor die Hasmonitiese Judaïste, het die Henogitiese Judaïsme 'n sonkalender gevolg soos wat in die Qumrantekste gesien kan word. Die tekste wat in die besonder van belang is om die Henogitiese kalender te verstaan, is die geskrif van Jobeil, die onderskeie kalendertekste in Qumran ${ }^{13}$ en die geskrifte van Henog (Talmon [1951] 1989:157, 163164). Uit hierdie tekste kan ' $n$ jaarindeling afgelei word wat uit 364 dae per jaar bestaan en deur sewe deelbaar is om presies 52 weke uit te maak. Die maande bestaan uit 30 dae elk, wanneer daar 'n ekstra dag aan die einde van die 3de, 6 de, 9 de en 12de maand gevoeg word sodat dié maande uit 31 dae bestaan. Die kalender is suiwer wiskundig op grond van die son bepaal sodat die maan geen rol gespeel het nie. Die weke is aaneenlopend en die dagindeling strek van oggend tot oggend, gekombineerd met ' $n$ liturgiese kalender wat binne die oggend-tot-oggend-dagindeling van aand tot aand strek. Vanweë die feit dat die weke presies deur die jaar deelbaar is, het dit veroorsaak dat die feeste elke jaar nie net op dieselfde kalenderdag geval het nie, maar ook op dieselfde weeksdag. Dit het die karakter van die Paasfees se aard as 'bepaalde tyd' nog meer 'bepaald' gemaak. ${ }^{14}$ Die Paasfees het elke jaar op 14 Abib begin, wat elke jaar op die tweede dag van die week (Dinsdag) geval het en liturgies teen die aand begin het. ${ }^{15}$

Die belangrikste eienskap van die Henogitiese Quartadecimane is dat hulle kalender vas bepaal is en dat hulle Paasfeesviering ' $n$ vaste patroon vorm. Die rede hiervoor is dat hulle die Henogkalender volg wat nie net jaarliks op 14 Abib val nie, maar ook jaarliks op dieselfde weeksdag, naamlik die derde weeksdag (Dinsdag), val.

\section{Henogitiese Quartadecimane se begronding op die Pasgamaaltyd van Christus}

Die tweede etiologiese begronding van die Henogitiese Quartadecimane was op die Pasgaviering van Jesus en sy dissipels die aand vóór sy kruisiging. Hulle het die tradisie gehandhaaf dat Jesus ook die Pasga op hierdie wyse gevier het, in teenstelling met die Pasga wat die Hasmonitiese Judaïsme die aand ná die kruisiging gevier het (Jaubert 1957:89-90; Saulnier 2012:33-36). 12.Midr. Psalms 104:19; b. Pesah.68a; Sanh.91b; Rashi ad Jes.30:26; Rashi ad Sag.4:2;
Ex. Rab. 15:21; Rosh Hasjana 1:1-3f; 2:5-7; 3:1; Sanhedrin 1:2; Tos. Sanhedrin 2:6;
Bab. Sanhedrin 11a-b; Jer. Megillah 1:4; Jer. Erubin 3:8-9; m. Sukk. 5:6-8; b.
Sukk.55b-56b; b. Moed Qat. 17b; Hand.9:1; 22:5; 28:21; Beckwith 2005:11-12, 25;
Humphreys en Waddington 1992:334-336; Jaubert 1957:19; Saulnier 2012:22;
Talmon [1951] 1989:169; Talmon, Ben-Dov en Glessmer 2001:3, 8, 33; Vanderkam
1998:35-38.

13.4Q320-330, 337, 394:1-2

14.b. Erub. 56a; 1 Henog 72-82; 4Q320-330, 337, 394:1-2; Jobeil 5:23; 6:32 Boccaccini 2002:75; Beckwith 2005:83, 89, 113; Glessmer 1999:244; Jauber 1957:19-20; Talmon [1951] 1989:164; Talmon, Ben-Dov en Glessmer 2001:1-3, $41-42,68,83,95,100,104,114,120,124-125,134,139-140,143-144,147-148$, 151-152; Saulnier 2012:22-23; Vanderkam en Flint 2004:212, 257; Vermes 2004:347.

15.4Q320:4iii:2; 321a:I:3; 321:IV:8-9; 325:I:1; 326:2; 329a:1-2; 329:1:1; 239:2a,b:4;

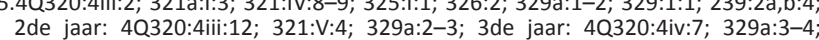
321:V:8-9; 4de jaar: 4Q320:4v:1; 321:III:8; 329a:4-5; VI:3; 5de jaar: 4Q320:4v:10 321:VI:7; 329a:5-6; 6de jaar: 4Q320:4vi:6; 321:VII:2; 329a:6; Talmon [1951] 1989:161-162.
Daar bestaan verskeie hipoteses aangaande die bepaling van die kruisiginggebeure se kronologie (Hoehner 1974: 'The Friday crucifixion'). Twee van hierdie hipoteses sluit die viering van Jesus se Pasgamaal in en bepaal dit volgens die Henogitiese kalender as Dinsdagaand. Hierdie twee hipoteses is die hipotese van die twee Pasgas en die een van die verlengde lyding (Jaubert 1957:89-90; Saulnier 2012:33-36). Beide hipoteses bepaal dat Jesus en sy dissipels die Pasga op 14 Abib ooreenkomstig die Henogitiese kalender genuttig het. Waar die twee hipoteses van mekaar verskil, is oor wanneer die kruisiging plaasgevind het en daarom ook op watter weeksdag die tweede Pasga val wat die aand ná die kruisiging van Jesus aangebreek het (Jaubert 1957:116-118; Saulnier 2012:39-41). Dit sou dan die Pasga-aand wees van die Hasmonitiese Judaïsme, soos verteenwoordig is deur die Sadduseërs en veral die Fariseërs. ${ }^{16}$ Die verskil lê daarin dat Jesus se kruisiging volgens die hipotese van die twee Pasgas op die Woensdag plaasgevind het, die dag ná die Pasgamaal. Die kruisiging volgens die hipotese van die verlengde lyding het eers die Vrydag plaasgevind (Jaubert 1957:13-75, 108-133; Saulnier 2012:19-33, 37-44). Die hipotese van die twee Pasgas is deur die navorser ontwikkel in sy doktorale proefskrif. Dit is gebaseer op die vier kanonieke evangelies se kronologie van die kruisiginggebeure sowel as die Evangelie volgens Petrus.

Die probleem met beide hipoteses is dat tyd in die teks ingelees word, sonder dat dit in die teks beskryf word. Volgens die hipotese van die twee Pasgas het die tyd wat Jesus in die graf was, nie net, soos in die tradisionele hipotese, van die Vrydag tot Sondagoggend geduur nie (Hoehner 1974: 'The Friday crucifixion'), maar van Woensdagaand af. Volgens die hipotese van die verlengde lyding is Jesus nie op dieselfde dag gekruisig as wat Hy gevange geneem is nie, maar is Hy die Woensdagoggend gevange geneem en het Hy tot Donderdagoggend onder gesag van die Sanhedrin in aanhouding gebly. Donderdagoggend is Hy na Pilatus geneem, waar $\mathrm{Hy}$, behalwe toe hulle Hom na Herodes gebring het, tot Vrydagoggend in aanhouding gebly het. Vrydagoggend is Hy gekruisig (Jaubert 1957:116-118; Saulnier 2012:39-41). Terwyl die gebeure beskryf word in die kanonieke evangelies, verswyg die evangelies die tydmerkers om dagskeidings tussen hierdie gebeure te beskryf (Jaubert 1957:116; Saulnier 2012:40).

Die navolging van die tradisie om die twee Pasgas te onderskei van Paasfeesviering sou afhanklik wees van een van hierdie twee hipoteses wat hulle sou kies. Die verskil wat in die hipoteses voorkom, waar beide die Henogitiese Quartadecimane behandel, sou dus nie wees wanneer die Pasga begin nie, maar waar Christus se kruisiging inpas in die Paasfees. Beide is dit eens dat Jesus die Sondag opgestaan het (Saulnier 2012:31). Omdat die Henogitiese Quartadecimane waarskynlik die Ou Testamentiese Agtdaagse Paasfees gevier het, sou hulle fees op Dinsdag 14 Abib begin en op Woensdag 21 Abib eindig. Die bepaling van die dag van Jesus se kruisiging, hetsy op Woensdag of

16.Bab. Sanhedrin 43.a; Flavius Josephus: Antiquitates Judaicae $3: 248$; Philo Judaeus: De Vita Mosis 222; Misjna Moed Pesachim 3:6; 5:4, 9. 
Vrydag, sou slegs mimetiese invloed op die inhoud van hulle fees gehad het, maar nie die etiologiese basis beïnvloed nie.

\section{Eliminasie deur wat die Henogitiese Quartadecimane nié was nie}

Hierna sal voorbeelde aangetoon word wat moontlik kan dui op die gebruik of vergestalting van die Henogitiese Quartadecimane. Ook word aangetoon dat daar nie direkte en konkrete uiteensetting of sistematiese uiteengesette Paasfeesbepalings van die Henogitiese Quartadecimane bestaan nie. Een van die belangrikste wyses om hulle gebruik te identifiseer is grootliks gegrond op eliminasie.

Een belangrike eienskap van die Henogitiese Quartadecimane is dat hulle twee Pasgas tydens die kruisiginggebeure erken. Hulle handhaaf juis die Henogitiese Pasga in opposisie van die Hasmonitiese Pasga. Die Henogitiese Pasga was dié wat Jesus en sy dissipels genuttig het. Die Hasmonitiese Pasga was die Pasga van die Jode of 'hulle Pasga' wat ná die kruisiging aangebreek het (Jaubert 1957:13-75, 108-133; Saulnier 2012:19-33, 37-44). Dit is dus in konflik met die Sinoptiese Quartadecimane, wat slegs die ete van Jesus as die Pasga erken het, of die Johannese Quartadecimane, of die Anti-Quartadecimane, wat slegs die Pasga ná die kruisiging as Pasga tydens die kruisiginggebeure erken het (Perler 1966:182; Richardson 1973:80; Stewart-Sykes 1998:154; Strobel 1977:19-22). Die Henogitiese Quartadecimane bepaal ook nie ooreenkomstig die Hasmonitiese of Lunêre Quartadecimane wat 14 Abib volgens die son-maankalender, dus die Rabbynse kalender, bepaal het nie. ${ }^{17}$

Omdat die Henogitiese Quartadecimane die Hasmonitiese Pasga tydens die kruisiginggebeure erken het, was Jesus ook simbolies die Pasgalam, maar nie dieselfde klem is daarop gelê as deur die Johannese Quartadecimane of AntiQuartadecimane nie. Hulle het waarskynlik saam met die Sinoptiese Quartadecimane gestem oor die etiologiese begronding van die Paasfees op die Pasgamaal van Jesus. ${ }^{18}$ Hulle het wel verskil in dié opsig dat hulle twee Pasgas erken het tydens die kruisiginggebeure en nie slegs een soos die Sinoptiese Quartadecimane nie (Stewart-Sykes 1998:154). Hulle kon ook verskil het rakende die kalender wat gebruik is om 14 Abib te bepaal, aangesien die Sinoptiese Quartadecimane nie noodwendig die Henogitiese of sonkalender gebruik het nie.

\section{Die Petrus-evangelie: eerste spoor van Henogitiese Quartadecimane \\ Eerste spoor van kruisiging vóór Vrydag}

Die eerste tradisie wat die kruisiging vóór Vrydag plaas, is die Evangelie volgens Petrus. Die rede waarom dit van belang

17.Eusebius Pamphilii: Historia Ec 5:23:1; Leonhard 2006:154; Mosshamme 2008:109-110, 137-138.

18.Stewart-Sykes 1998:154; Chronicon Paschale: Patrologia Graeca 92:80B; Gerlach 1998:367-368; Origenes: Commentarium in Matthaeum ser. 79; GCS 38:188; Gerlach 126-127. is, is dat dit wys op 'n tradisie wat die Pasga van Jesus vóór Donderdag plaas, soos dit in die tradisionele hipotese rakende die kruisigingsgebeure voorkom. Dit pas daarom nie in by die hipotese van die verlengde lyding nie, maar slegs by dié van die twee Pasgas of alternatiewe hipotese. Alhoewel die teks nie die Henogkalender weergee nie, ook nie die Pasgamaal op die Dinsdag plaas of ' $n$ spesifieke kalender aanbied nie, is dit 'n alternatiewe tradisie wat die kruisiging vóór Vrydag plaas.

\section{Agtergrond van die teks}

In die teks self identifiseer die skrywer hom as Petrus, die dissipel van Jesus (Ehrman 2005:31; Van der Watt \& Tolmie 2005:447-478). Rakende die datering van hierdie evangelie, bestaan daar twee groepe opinies en hipoteses. Die een groep verklaar dit 'n baie ou tradisie wat selfs nog vroeër as die kanonieke evangelies of dieselfde tyd as die sinoptiese evangelies kan wees. Die ander verklaar dit 'n teks van die 2de eeu n.C. wat, nadat die outeur die kanonieke evangelies herhaaldelik gehoor het, uniek ontwikkel het. Indien hierdie teks die Evangelie volgens Petrus is, moes dit reeds van die einde van die eerste eeu bestaan het, aangesien Serapion, biskop van Antiochië, daarna verwys het (Gerlach 1998:191; Van der Watt \& Tolmie 2005:478-479).

Die teks begin eers ná die maaltyd van Jesus en dit is daarom nie moontlik om te bepaal wat die outeur se siening oor die status van Jesus se ete was of wanneer dit plaasgevind het nie. Die outeur sluit wel aan by die kronologie van Johannes in die direkte uiteensetting van die Pasga wat plaasvind ná Jesus se kruisiging (Gerlach 1998:191-192; Stewart-Sykes 1998:26).

In die teks gaan vra Josef (van Arimathea) Jesus se liggaam van Pilatus en Pilatus vra dit op sy beurt van Herodes. Herodes antwoord dat hy dit sou gee omdat dit nie op 'n Sabbat mag bly hang nie. Die volgende dag sou dus 'n Sabbat wees. Dit word ook deur die skrywer self gestel dat Jesus oorgelewer is aan die Jode 'voor die eerste dag van die Ongesuurde Brode'. Die verwysing na 'hulle fees' (Beckwith 2001:294-295; Elliot 2007:154; Ehrman 2005:32; Van der Watt \& Tolmie 2005:480) kan moontlik dui dat die outeur twee Pasgas erken het, terwyl die Hasmonitiese Pasga ná die kruisiging aangebreek het.

Die Sabbat sou hier na die weeklikse Sabbat kon verwys. Dit is egter vers 27 wat ' $n$ ander vertolking as weeklikse Sabbat vereis. Nadat Jesus oorgegee is, is Hy gekruisig. Hierop volg die kruisigingbeskrywings totdat Hy om ongeveer drieuur die middag sterf (Leonhard 2006:228; Stewart-Sykes 1998:125). In hierdie tyd word nie verdere inligting rakende die kalendriese aspek gegee nie, behalwe die tyd van kruisiging. Ná Jesus se begrafnis beskryf die evangelieskrywer dat die dissipels saam vergader het uit vrees vir die Jode. Dan skryf hy: 'Ons het gesit en rou en huil, dag en nag, totdat dit

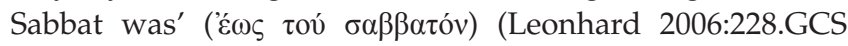
11.38.7-9). 
Vers 5 beskryf dat Jesus voor die Sabbat gekruisig is, waar die Sabbat en Pasgadag dieselfde dag is en beskryf word as 'hulle fees'. Dit kan daarom vertolk word dat hulle die Pasga self as 'n Sabbat beskou het sodat dit nie noodwendig na die weeklikse Sabbat verwys nie. Dit kon die Donderdag of vroeër gewees het. Die Vrydagaand breek die weeklikse Sabbat aan. Dit is die enigste logiese interpretasie van vers 27 waar die dissipels 'dag en nag gerou en gehuil het totdat dit Sabbat was'. Indien die kruisiging op die Vrydag was, het die weeklikse Sabbataand aangebreek met sy begrafnis, en sou hierdie gedeelte nie sin maak nie (Leonhard 2006:228 n. 307). In die teks word die Paasfees Sabbat (5) onderskei van die 'Sabbat vóór die opstanding' (7, 34, 50).

Omdat hierdie gedeelte nie inpas in die tradisionele hipotese van Vrydag se kruisiging nie, het daar verskeie hipoteses ontstaan om dit te probeer inpas sodat dit sin kon maak binne die tradisionele hipotese. Die hipoteses hou nie stand nie en sodra 'n oplossing gebied word, veroorsaak dit nuwe probleme, sonder dat 'n volledige oplossing gebied word (Leonhard 2006:228; Vaganay 1930:274).

Brown (1994:1340) verklaar dat 'deur die Sabbat' ingelees moet word in plaas van 'tot op die Sabbat'. Behalwe dat die teks dit nie weergee nie, los dit nie die 'dag en nag' op wat dit sou duur nie (Leonhard 2006:228). Crossan (1988:23) verklaar dit as die sewende dag van die Fees van die Ongesuurde Brode en dieselfde Sabbat as vers 50 . Dit bied ook nie 'n oplossing nie, aangesien die 'dag van die Here' reeds aangebreek het tussen verse 27 en 58 (v. 34-35, 50). Selfs al is dit nie die 'dag van die Here' genoem nie, beskryf die teks steeds 'n dag tussen die Sabbat van vers 27 en dié van vers 58 sodat dit nie na dieselfde dag kan verwys nie. Gerlach (1998:192) stel dat dit selfs moontlik 'n skryffout van die outeur kan wees. Rouwhorst (1989:I:162; II:139; Leonhard 2006:228) verklaar dat dit 'n baie kort vas was van drie ure en lei moontlik die Quartadecimaanse gebruik in van drie ure vas, soos wat in die Didaskalia voorkom.

\section{Evangelie volgens Petrus en die tema van 'Lam van God'}

Daar bestaan verskeie opinies oor die afhanklikheid van die Evangelie volgens Petrus ten opsigte van die kanonieke evangelies. Die teks is in 'n groot mate ' $n$ unieke tradisie en daar kom geen direkte ooreenstemmings van frases tussen die Evangelie volgens Petrus en die kanonieke evangelies, soos in die sinoptiese evangelies, onderling voor nie. Daar bestaan ook ooreenstemmings en verskille ten opsigte van die kanonieke evangelies met betrekking tot kronologie, teologiese temas en fokus of klem op sekere aspekte (Elliot 2007:150; Leonhard 2006:229; Mara 1973:214; Stewart-Sykes 1998:153; Van der Watt \& Tolmie 2005:478-479).

Een van die belangrikste simboliese aspekte wat veral van belang vir die analisering van die kalendriese aspek van die Paasfees is, is dat Jesus die Pasgalam is wat op die tyd geslag is wat die Hasmonitiese Pasgalam geslag moes word. Vir die
Johannese tradisie is dit ' $n$ baie belangrike aspek. Nie net stem dit met Johannes se kronologie ooreen nie, maar in Johannes se geskrifte, veral Openbaring, word die teologiese simboliek dikwels herhaal dat Jesus die 'Lam van God' is. Binne hierdie konteks beeld Johannes Jesus uit as die Pasgalam wat op die presiese tyd vóór die Pasga-ete gekruisig is. Johannes bring 'n direkte verwysing na Jesus as Pasgalam waar hy die parallel trek tussen die Pasgalam waarvan die bene nie gebreek moet word nie en Jesus wie se bene nie aan die kruis, soos dié van die ander, gebreek is nie (Joh 19:36). Die Evangelie volgens Petrus sluit by Johannes se kronologie aan, maar nie by die teologiese gedagte van Jesus as Pasgalam nie (Stewart-Sykes 1998:153-154). In elk geval nie eksplisiet soos wat Stewart-Sykes (1998:150, 152) en Mara (1973:82) dit veronderstel nie. Die Evangelie volgens Petrus noem Jesus nooit die Lam nie en anders as Johannes verklaar dit dat Jesus se bene wel gebreek is, weens die haat van die Jode teenoor Hom en nie omdat Hy reeds dood was en as vervulling van die Skrifte nie. ${ }^{19}$

Stewart-Sykes en Mara veronderstel dat die teks slegs een Pasga tydens die kruisgebeure weergee, wat waarskynlik nie so is en ook nie bewys kan word nie omdat die teks eers ná Jesus se Pasgamaal begin. Dit pas dus by die die Henogitiese Quartadecimane in om Jesus se kruisiging te plaas op die tyd wat die Hasmonitiese Pasgalam geslag moes word, sonder sterk klem op Jesus as Pasgalam, soos dit in die Johannese Quartadecimane en Anti-Quartadecimane voorkom.

\section{Evangelie volgens Petrus oor die Agtdaagse Paasfees}

Stewart-Sykes (1998:26) stel dat die Quartadecimane van 14 Abib tot Sondag gevas het en dat dit op die Evangelie volgens Petrus gegrond was. Dit is nie waar nie, aangesien daar gesien kan word uit die evangelie dat die dissipels vir die totale duur van die Paasfees saamgekom het en eers daarna vertrek het. Dit word wel nie gestel of dit ooreenkomstig die Henogitiese of Hasmonitiese kalender was nie.

Hieruit kan gesien word dat die Henogitiese Quartadecimane meer etiologies klem op die Ou Testament geplaas het deur steeds die Agtdaagse Paasfees te vier en dit nie die Sondag met die opstanding beëindig het nie (Richardson 1973:80; Stewart-Sykes 1998:152). In hierdie hoedanigheid sluit hulle in ' $n$ mate aan by die Judaïstiese Quartadecimane, soos byvoorbeeld Blastus (Stewart-Sykes 1998:154), behalwe dat die Henogitiese Quartadecimane nie die Hasmonitiese kalender gevolg het nie, maar juis die Henogkalender in opposisie van die Hasmonitiese en later Rabbynse Judaïsme.

Die teks van die Evangelie volgens Petrus is die oudste Christelike tradisie wat ondubbelsinnig wys dat daar Christene was wat die Agtdaagse Paasfees herdenk het (Leonhard 2006:206, 224-226; Rouwhorst 1989:I:154, 2004:63-85).

19.Evangelie volgens Petrus 4(14); Gerlach 1998:191-192. 


\section{Melito van Sardis}

Melito, biskop van Sardis, word deur Eusebius prominent aan die tweede fase van die Quartadecima-vraagstuk gekoppel. Eusebius beskryf dat die tweede fase in Laodicea ontstaan het. ${ }^{20}$ Die tweede fase het tussen ongeveer 160 en 170 n.C. gestrek, met Melito van Sardis en Apollinarius van Hiërapolis wat as die twee prominente rolspelers genoem word. $^{21}$

Daar is baie min oor die lewe van Melito bekend. ${ }^{22}$ Eusebius verwys in sy Kerkgeskiedenis 4:13, 26 na agtien van Melito se werke, waarvan die meeste vandag verlore is. In die helfte van die 20ste eeu is verskeie tekste van 'n volledige preek van Melito ontdek, genaamd die 'Preek aangaande die Pasga', wat voorheen slegs deur fragmente van die teks bekend was (Blank 1963:22-23; Bonner 1940; Douglas, Comfort \& Mitchell 1992; Gerlach 1998:61-62; Lohse 1953; Kenyon 1941; Van Goudoever 1961:155).

Ondanks verskeie opinies oor die status van Melito as Quartadecimaan, kan gesê word dat die 'Preek aangaande die Pasga'23 geen direkte kalendriese aspek van die Paasfees weergee nie (Stewart-Sykes 1998:7, 40-41). Afleidings wat gemaak word, is slegs indirek op grond van die klem wat hy op seker temas plaas, kronologie waarby hy aansluit en vertolking van die kruisiginggebeure. Selfs die indirekte afleidings is nie baie duidelik dat Melito 'n Quartadecimaan was nie. Was dit nie vir die derde party, naamlik Polikrates wat Melito duidelik as Quartadecimaan beskryf het nie, sou die 'Preek aangaande die Pasga' moeilik as konkrete bewys van Melito se status as Quartadecimaan kon gewees het. Daar gaan dus nie in baie besonderhede by Melito en die indirekte afleidings stilgestaan word nie.

\section{Polikrates van Efese (139-196 n.C.)}

Die eintlike voorbeeld wat die gebruik van die Henogitiese Quartadecimane vertolk, is Polikrates, biskop van Efese. Eusebius verwys na Polikrates in sy Kerkgeskiedenis (5:22; 5:24:1) as een van die belangrikste rolspelers van die derde fase van die Quartadecima-vraagstuk.

In Eusebius se beskrywing van die derde fase, plaas hy die parogieë van Klein-Asië se Paasfeesgebruik in kontras met 'die res van die wêreld' se gemeentes. Dit sluit in Rome, Aleksandrië, Palestina, die Weste en sekere dele van Sirië (Gerlach 1998:325). Hy verklaar dat Klein-Asië die 'ouer tradisie' gevolg het, terwyl die ander die 'apostoliese tradisie'

20.Eusebius Pamphilii: Historia Ecclesiastica 4:26:3; Gerlach 1998:319.

21.Eusebius Pamphilii: Historia Ecclesiastica 4:26:1-8; Stewart-Sykes 1998:155-156.

22.Roberts en Donaldson 1997 VIII: Melito, the Philosopher; Douglas et al. 1992: Melito; Knight 2003: St. Melito; Blank 1963:13-21; Eusebius Pamphilii: Historia Ecclesiastica 4:21:1; 5:24.

23.Engelse vertaling: Bonner 1940: The homily on the passion by Melito bishop of Sardis, in: Studies and Documents XII. Londen: Christophers. Duitse vertaling: Blank 1963: Meliton von Sardes: Vom Passa - Die älteste christliche Osterpredigt. 1963: Meliton von Sardes: Vom Passa - Die älteste christliche Osterpredigt. Freiburg im, Breisgau:
Melito Apol. 1495 001). gevolg het. ${ }^{24}$ Gerlach (Brox 1972:309; Gerlach 1998:325; Leonhard 2006:270) maak die opmerking dat indien die tradisie nie bly voortbestaan nie, of nie algemeen gehandhaaf word nie, dit ' $n$ 'ouer tradisie' is. Die voortbestaan van die tradisie dui dan juis op die 'apostoliese aard' van 'n tradisie en word as sodanig geklassifiseer indien dit gehandhaaf word of in die algemeen voorkom.

Eusebius haal 'n gedeelte van 'n brief van Polikrates aan wat hy aan Victor, biskop van Rome, geskryf het om juis KleinAsië se apostoliese navolging te verdedig, soos dit 'aan hulle oorgelewer' is. ${ }^{25}$ In Polikrates se brief beroep hy hom op sewe voorgangers waarvan twee apostels was, naamlik Johannes en Philippus. Die ander vyf was Philippus se dogters, Polikarpus van Smirna, Thraseas van Eumenia wat in Smirna ontslaap het, Sagaria wat in Laodicea ontslaap het, Papirius en dan ook Melito van Sardis. Hy skryf ook die brief namens "n groot menigte wat byeengeroep is' en dus Klein-Asië vergestalt. ${ }^{26}$

Polikrates beskryf dan dat hulle 'die 14de dag van die Pasga gevier het ooreenkomstig die evangelie, terwyl hulle in geen aspek daarvan afgewyk het nie, maar die reël van die geloof gevolg het'. Die 'evangelie' kan op twee maniere vertolk word. Dit kan eerstens dui op die evangelie as die 'blye boodskap', die 'boodskap van Christus' en die 'boodskap van die Christendom'. Tweedens kan dit verwys na 'n enkel evangelie wat waarskynlik dié van Johannes sou wees, vanweë die prominensie van Johannes (StewartSykes 1998:13-14, 37) en die tradisie dat hy die evangelie in Efese geskryf het (Brent 1995:65). Dit wil uit die teks self voorkom dat ondanks Johannes se prominensie eerder verwys word na die 'evangelie' as abstrakte verwysing en versamelnaam na die evangelie van Christus. Die verwysing daarna as die navolging van die 'reël' of 'kanon van die geloof' dui daarop dat die eerste opsie meer sin maak (Stewart-Sykes 1998:152-153).

Die verklaring dat die Henogitiese Quartadecimane die Pasgaviering etiologies op die evangelie begrond, plaas hulle in kontras met die Judaïstiese of Wettiese Quartadecimane, soos Blastus, wat die Pasgaviering etiologies grootliks op die wet begrond het. ${ }^{27}$ Omdat hulle die viering op die evangelie begrond het, beteken dit dat hulle dit óf mimeties op die kruisgebeure begrond het óf etiologies op die wyse waarop Christus en die dissipels die Pasga gevier het,.

Op grond van Polikrates se brief, sowel as Eusebius se beskrywing, wil dit voorkom of hulle dit eerder etiologies as mimeties begrond het. Polikrates beskryf dat 'hulle in geen

24.Eusebius Pamphilii: Historia Ecclesiastica 5:23:1; Gerlach 1998:324-325.

25.Eusebius Pamphilii: Historia Ecclesiastica 5:24:1-8; Gerlach 1998:328; Mosshammer 2008:48.

26.Eusebius Pamphilii: Historia Ecclesiastica 5:24:8; Stewart-Sykes 1998:12-13; Mosshammer 2008:48; Leonhard 2006:45.

27.Tertullianus: Adversus omnes haereses 8:8; Gerlach 1998:329, 372, 374; Zernov 1993:25; Richard 1965:198; Brent 1995:64-65; Leonhard 2006:271, 284; Stern 2001:49; Huber 1969:25, 70-73; Stewart-Sykes 1998:36-37, 151-153; Lieu 1996:228. 
aspek van die navolging van die geloofsreël van die evangelie afgewyk het nie'. Hy verklaar dit self deur te stel dat hy soos al sy voorgangers die dag altyd herdenk 'wanneer die volk die suurdeeg weggebêre het'. Hierdie beskrywing skep die moontlikheid dat dit eerder dui op die etiologiese navolging van die Pasgaviering, wat selfs terugstrek tot die wet en dus as sodanig deur Christus en sy dissipels gevier is (Leonhard 2006:270; Schürer 1973-1987:iii:22-23; Stern 2001:222-223). Polikrates het dit dan ontvang deur die oordrag van die apostels Philippus en Johannes.

Daar bestaan twee mimetiese begrondingsmoontlikhede. Die een is simbolies van aard en die ander kronologies. Die simbolies mimetiese begronding is geleë in Jesus wat as die Pasgalam geslag is, vóór die aanbreek van die Pasga-aand van die Hasmonitiese Judaïsme. Die Anti-Quartadecimane het klem hierop gelê (Cullen 2007:44-45; Roberts \& Donaldson 1997a II: 'Fragments of Clemens of Alexandria: XI: From the last work on the Passover'; Souvay 1929-1930:43-62; StewartSykes 1998:157-158). Dit is duidelik dat Polikrates en KleinAsië in opposisie hierteen gestaan het (Gerlach 1998:325, 361). Die tweede moontlikheid is dat hulle die Pasga herdenk het soos dit in die Evangelie volgens Johannes beskryf word as die aand ná die kruisiging (Stewart-Sykes 1998:41). Dit sou dan in aansluiting wees by die Johannese Quartadecimane. Nogtans het die Johannese Quartadecimane sterk klem op die simboliek van Jesus as die Lam van God gelê as deel van hulle rede tot bepaling van die Paasfees (Stewart-Sykes 1998:40, 154-155, 158), wat nie hier ter sprake is nie. Nieteenstaande Johannes se prominensie dus, sou Polikrates nie inpas as Johannese Quartadecimaan nie.

Die etiologiese begronding van die Pasga verleen gewig aan die moontlikheid dat hy die Pasga gevier het, soos wat Christus dit gevier het. Dit bring die moontlikheid dat hy 'n Sinoptiese Quartadecimaan was. Vanweë die sterk klem op Johannes sou dit onwaarskynlik wees dat hy die Paasfees gevier het suiwer ooreenkomstig die sinoptiese evangelies, ten koste van die Evangelie volgens Johannes (Dugmore 1961; Schürmann 1951; Stewart-Sykes 1998:151). Dit beteken dat hy nie ooreenkomstig die sinoptiese evangelies slegs die maaltyd van Christus en sy dissipels as enigste maaltyd tydens die kruisgebeure sou erken ${ }^{28}$ ten koste van die Evangelie volgens Johannes nie, waar laasgenoemde ook 'n Pasga ná die kruisiging beskryf (Stewart-Sykes 1998:37-38, $40,154)$. Hy sou dus ook nie as Sinoptiese Quartadecimaan geklassifiseer kan word nie (Leonhard 2006:284; Rouwhorst 2005). Dit laat die opsie van Hasmonitiese en Henogitiese Quartadecimaan (Stewart-Sykes 1998:152).

Daar is ' $n$ paar faktore wat daarop dui dat Polikrates eerder as Henogitiese Quartadecimaan geklassifiseer moet word. Een van die kenmerkendste eienskappe van die Henogkalender en die Henogitiese Quartadecimane, is die konsekwentheid en vastigheid van die Paasfees in die kalender. Die feit dat die Henogkalender se kalenderdae elke jaar op dieselfde weeksdag val, veroorsaak dat die bepaling dat die Pasga-aand elke jaar op 14 Abib val, wat beteken skemeraand van die derde weeksdag, Dinsdag. Polikrates skryf vervolgens in sy brief ${ }^{29}$ dat hulle 'die presiese dag' onderhou en 'niks byvoeg of aftrek nie'. Hierdie konstantheid of presiesheid wat nie aanskuif of terugskuif nie, skep die indruk dat hulle die Henogitiese kalender gevolg het.

Indien hy etiologies aansluit by die Pasgamaal wat Christus saam met sy dissipels genuttig het, soos in die sinoptiese evangelies beskryf word, tesame met die prominensie wat die Evangelie volgens Johannes in Klein-Asië geniet het, verskerp die moontlikheid dat hulle die twee Pasgas tydens die kruisiginggebeure erken het (Richardson 1973:75; Weitzel 1848). Dit is ook een van die eienskappe van die Henogitiese Quartadecimane. Hulle het dus die Pasga gevier in ooreenstemming met die gebruik van Jesus, soos Hy dit saam met sy dissipels gevier het. Dit was volgens die Henogkalender, wat 'n dag (volgens die hipotese van die twee Pasgas) of drie dae (ooreenkomstig die hipotese van die verlengde lyding) (Jaubert 1957:116-118; Saulnier 2012:39-41) vóór die Hasmonitiese Pasga, wat die aand ná die kruisiging aangebreek het.

Eusebius $^{30}$ se vertolking van Klein-Asië en Polikrates sluit aan die een kant hierby aan wanneer hy beskryf dat die 'ouer tradisie' van Klein-Asië was om Pasga op die 14de van die maand te vier, noukeurig as die 'Verlosser se fees'. Die indruk wat dit skep, is dat die Pasga vir hulle beteken het om dit in navolging van Jesus se viering te vier.

Aan die ander kant is Eusebius se beskrywing van Polikrates en Klein-Asië eerder duidend op dié van die Hasmonitiese Quartadecimane, sodat hulle die Pasga op 14 Abib gevier het, maar volgens die son-maankalender. Dit is die kalender wat deur die Hasmonitiese Judaïsme gebruik is en oorgedra is aan die Rabbynse Judaïsme. Die belangrikste kenmerk van hierdie kalender, en so ook van die Hasmonitiese Quartadecimane, is dat die weeksdag waarop 14 Abib elke jaar val, varieer. Eusebius beskryf dat Klein-Asië die 14de onderhou 'op die dag waarop die Jode beveel is om die lam te offer'. Hierdie beskrywing sou ook nog op beide die Hasmonitiese sowel as Henogitiese Quartadecimane kon dui, aangesien die Pasgalam wat geslag word as kalendriese aspek vir beide geld. Maar hy voeg by: 'dat hulle die vas staak op $14 \mathrm{Abib}$, op watter dag van die week dit ook al sou gebeur'. Volgens Eusebius se beskrywing het Klein-Asië óf die gebruik van die Hasmonitiese Quartadecimane vergestalt ${ }^{31}$ of Eusebius was verkeerd in sy siening oor die Quartadecimaanse gebruik in Klein-Asië, veral ten opsigte van die datum en bepaling daarvan.

In beoordeling van Eusebius se beskrywing moet onthou word dat hy vanuit 'n vierde-eeuse perspektief skryf oor gebeure wat langer as ' $n$ eeu vantevore plaasgevind het 29.Eusebius Pamphilii: Historia Ecclesiastica 5:24:2.

30.Eusebius Pamphilii: Historia Ecclesiastica 5:23:1.

31.Stern 2001:222; Leonhard 2006:269, 271-272; Epifanius: Panarion 70:10:2. 
(Gerlach 1998:325). Verder skryf hy binne die konteks vanuit Palestina en vertroud met die 4de-eeuse Rabbynse gebruik van Paasfeesbepaling (Leonhard 2006:269-270; Mohrmann 1962:159). Verder fokus hy ook meer op wie by aspekte betrokke was en wanneer dit plaasgevind het, as op wat die kwessies was. ${ }^{32}$ Dit is daarom moontlik dat hierdie beskrywing van Eusebius 'n 4de-eeuse indruk van die Quartadecimaanse gebruik was en nie noodwendig Polikrates se gebruik weerspieël nie.

Strobel (1977:352, 389-392, 449) steun laasgenoemde hipotese en verklaar dat Klein-Asiatiese navolgers van die Henogitiese Quartadecimaanse gebruik is. Hy noem hulle die Solariese Quartadecimane wat 'n suiwer sonkalender volg ooreenkomstig die Qumrankalender. Hy begrond sy hipotese egter op die vierde-eeuse Montaniste soos beskryf in Sozomenus. ${ }^{33}$ Strobel beweer dat die vierde-eeuse groep 'n gebruik gevolg het wat baie ver in die geskiedenis terugstrek, en dat hulle die algemene gebruik van Klein-Asië nagevolg het en laasgenoemde dié van die Qumrankalender. ${ }^{34}$

\section{Spore van die Henogitiese Quartadecimaanse gebruik in die Didaskalia}

Strobel (1977:228, 352, 389-392, 449) verklaar dat die gebruik van die Henogitiese Quartadecimane in Antiochië voorgekom het, want een van die duidelikste spore van die Henogitiese tradisie kom voor in die Siriese geskrif Didascalia apostolorum (Leer van die apostels). Hy verklaar dat die gebruik vóór die konsilie van Nicea in 325 n.C. deur Klein-Asië laat vaar is en na Sirië en Mesopotamië versprei het. Die teks dateer uit ongeveer die helfte van die derde eeu n.C. (Roberts \& Donaldson 1997:VII: 'Constitutions of the Holy Apostles: Introductory Notes'; Gerlach 1998:166). Alhoewel die teks self 'n Anti-Quartadecimaanse gebruik veronderstel, stel dit dat Jesus die Pasga saam met sy dissipels op die derde weeksdag (Dinsdag) teen die aand genuttig het. Die Dinsdagaand se Pasgamaal-tradisie word dus erken, soos dit in die Henogkalender voorkom, maar die redakteurs van die teks het ' $n$ ander vertolking gebied in die verklaring waarom die Pasgamaal op die Dinsdagaand en nie op die Vrydagaand genuttig is nie. Die vroeër plasing van die Pasga word deur die outeurs verklaar as bedrog van die Joodse owerstes wat die Pasga van Vrydag na Dinsdag vervroeg het sodat hulle Jesus nie op die Pasga sou doodmaak nie. ${ }^{35}$

\section{Gevolgtrekking}

In die eerste drie eeue van die Christendom het daar verskeie strome ontstaan wat die Paasfees op verskillende wyses gevier het. Die twee hoofstrome is die Quartadecimane en die AntiQuartadecimane. Die Quartadecimane het die Pasga elke jaar

32.Leonhard 2006:270; Gerlach 1998:320; Eusebius Pamphilii: Historia Ecclesiastica 1:1:4.

33.Sozomenus Salaminus: Historia Ecclesiastica 7:18:12-14.

34.Strobel 1977:449; Kyk opposisie van Strobel: Gerlach 1998: 375.

35.Didaskalia 21; Gerlach 1998:203-230; Leonhard 2006:283; Jaubert 1957:74-75. op 14 Abib begin en die Anti-Quartadecimane op die Vrydag vóór die eerste (sommige selfs die tweede) Sondag wat ná die 14de Abib aanbreek. Binne hierdie twee hoofstrome het daar verskeie variasies voorgekom. Een van hierdie variasies binne die Quartadecimane was die Henogitiese Quartadecimane. Hulle het die Pasga bepaal ooreenkomstig die Henogkalender waar die Pasga elke jaar op 14 Abib begin is. Die 14de Abib het elke jaar konsekwent op die derde weeksdag geval sodat hulle die Pasga teen skemer die Dinsdagaand begin vier het. Hulle het dit etiologies op die Pasgamaal van Jesus begrond en sodoende indirek op die wet, ingesluit Henogitiese geskrifte soos in Qumran gevind is. Hulle het die mimetiese begronding nogtans nie totaal geïgnoreer nie, maar juis twee afsonderlike Pasgas tydens die kruisiginggebeure erken, naamlik die maaltyd van Jesus saam met sy dissipels (Henogitiese Pasga) en die een ná Jesus se kruisiging (Hasmonitiese Pasga). Die mimetiese begronding, naamlik Jesus as Pasgalam, was nie mimeties aan Jesus se kruisiging vóór die Hasmonitiese Pasga gekoppel nie.

Die eerste spore van die Henogitiese Quartadecimane wat opgespoor kan word, ná die evangeliese tydperk, buiten die kanonieke geskrifte, is in die Evangelie volgens Petrus. In hierdie evangelie word afgelei dat die kruisiging nie ooreenkomstig die tradisionele hipotese oor die kruisiging op die Vrydag plaasgevind het nie, maar ten minste die Donderdag of dalk vroeër. Dit is selfs moontlik dat die outeur twee afsonderlike Pasgas tydens die kruisgebeure erken het. Dit toon 'n Christelike groep aan wat steeds die Agtdaagse Paasfees gevier het.

Die prominentste voorbeeld van HenogitieseQuartadecimane is Polikrates, biskop van Efese. Hy is deur Eusebius se Kerkgeskiedenis as prominente persoon tydens die derde fase van die Quartadecima-vraagstuk teenoor Victor van Rome geplaas. Polikrates kan beskou word as woordvoerder van die Quartadecimane van Klein-Asië teenoor die AntiQuartadecimane van die 'res van die wêreld', in die besonder Rome. Hierdie fase speel af in die laaste dekade van die tweede eeu n.C.

Polikrates word as Henogitiese Quartadecimaan geklassifiseer. Die belangrikste rede vir hierdie identifisering is deur eliminasie van gegewens. Hy kan nie as Judaïstiese of Wettiese Quartadecimaan beskou word nie, aangesien hy die Pasga nie hoofsaaklik op die etiologie van die wet begrond het nie. Hy kan ook nie beskou word as Sinoptiese Quartadecimaan wat slegs die kronologie van die Sinoptiese evangelies ten koste van die Evangelie volgens Johannes gevolg en die Pasga sodoende suiwer etiologies op Jesus se Pasgamaal gegrond het nie. Hy kan nie as Johannese Quartadecimaan beskou word wat die Pasga slegs erken het tydens die kruisiginggebeure, wat ná die kruisiging was, en baie sterk klem op Jesus as Lam van God geplaas het nie.

Hy was dus óf 'n Hasmonitiese óf Henogitiese Quartadecimaan. Eusebius is verkeerd in sy beskrywing wat Polikrates as Hasmonitiese Quartadecimaan skets. In 
Polikrates se brief self dui dit eerder daarop dat hy 'n Henogitiese Quartadecimaan was.

Spore van die Henogitiese Quartadecimane kan gesien word in die derde-eeuse Didaskalia, waar Jesus se Pasgamaal pertinent op die derde weeksdagaand (Dinsdagaand) geplaas word. Ondanks hierdie tradisie wat die teks weergee, handhaaf die Didaskalia 'n Anti-Quartadecimaanse gebruik om nie die Pasga op 14 Abib te begin nie.

Die Henogitiese Quartadecimane was dus 'n groep met variante en eiesoortige Paasfeesgebruike, waar spore van hulle gebruik tot in die derde eeu n.C. geïdentifiseer kan word.

\section{Erkenning}

Bedanking aan prof. H.F. Stander van die Departement Antieke Tale en ander personeellede aan die Universiteit van Pretoria.

\section{Mededingende belange}

Die outeurs verklaar dat hulle geen finansiële of persoonlike verbintenis het met enige party wat hulle nadelig kon beïnvloed in die skryf van hierdie artikel nie.

\section{Outeursbydrae}

W.P. is die hoofskrywer. Die artikel is gebaseer op sy PhDnavorsing. J.M.v.d.M. was sy toesighouer en is mede-outeur van die artikel.

\section{Befondsing}

Die navorsing is deur die Universiteit van Pretoria befonds.

\section{Data beskikbaarheidsverklaring}

Data-deling is nie van toepassing op hierdie artikel nie, aangesien geen nuwe data in hierdie studie geskep of ontleed is nie.

\section{Vrywaring}

Die sienings en menings wat in hierdie artikel uitgedruk word, is dié van die outeur(s) en weerspieël nie noodwendig die amptelike beleid of posisie van enige geaffilieerde agentskap van die outeurs nie.

\section{Literatuurverwysings}

Baumgarten, A.J., 1995, Rabbinic literature as a source for the history of Jewish sectarianism in the Second Temple Period, DSD2. https://doi.org/ Jewish sectarianism in the
$10.1163 / 156851795 \times 00193$

Beckwith, R.T., 2001, Calendar and chronology, Jewish and Christian, revised edn., Brill, Leiden.

Beckwith, R.T., 2005, Calendar, chronology and worship, Brill, Leiden. https://doi. org/10.1163/9789047415473

Blank, J., 1963, Meliton von Sardes: Vom Passa-Die älteste christliche Osterpredigt, Lambertus, Freiburg im Breisgau.

Boccaccini, G., 1998, Beyond the essence hypothesis: The parting of the ways between Qumran and Enochic Judaism, Eerdmans, Grand Rapids, MI.
Boccaccini, G., 2002, Roots of Rabbinic Judaism, Eerdmans, Grand Rapids, MI.

Bonner, C., 1940, 'The homily on the passion by Melito, bishop of Sardis', in K. Lake \& S. Lake (reds), Studies and documents XII, Christophers, Londen.

Brent, A., 1995, Hippolytus and the Roman Church in the third century: Communities in tension before the emergence of a monarch-bishop, Brill, Leiden. https://doi. org/10.1163/9789004312982

Brown, R.E., 1994, The death of the Messiah: From Gethsemane to the grave: A commentary on the Passion narratives in the four Gospels, Yale University Press, Londen.

Brox, N., 1972, 'Tendenzen und Parteilichkeit im Osterfeststreit des zweiten Jahrhunderts', Zeitschrift für Kirchengeschichte 83, 291-394.

Crossan, D., 1988, The cross that spoke, Harper \& Row, San Francisco, CA.

Cullen, O.M., 2007, 'A question of time or a question of theology: A study of the Easter controversy in the Insular Church', unpublished Ph.d. thesis, Pontifical University St. Patrick's College, Maynooth.

Douglas, J.D., Comfort, P.W. \& Mitchell, D. (eds.), 1992, Who's who in Christian History? Tyndale House, Wheaton, IL.

Dugmore, C., 1961, A note on the Quartodecimans, in Studia Patristica, papers presented to the International Conference on Patristic studies 4, Texte und Untersuchungen zur Geschichte der Alchristlichen Literatur 79, Berlin.

Dumont, D.J. \& Smith, R.M., 1992-2002, Musaios 2002 Release A., electr. ed., viewed from https://www.musaios.com.

Ehrman, B.D., 2005, Lost scriptures - Books that did not make it into the New Testament, Oxford University Press, Oxford.

Elliot, J.K., 2007, The apocryphal New Testament, Oxford University Press, Oxford.

Gerlach, K., 1998, The antenicene Pascha, Peeters, Leuven.

Glessmer, U., 1999, 'Calendars in the Qumran scrolls', Flint \& Vanderkam 1999, 213-278.

Hoehner, H.W., 1974, 'Chronological aspects of the life of Christ. Part IV: The day of Christ's crucifixion', Bibliotheca Sacra 131(523).

Huber, W., 1969, Passa und Ostern. Untersuchengen zur Osterfeier der alten Kirche in, Beihefte zur Zeitschrift für die neutestamentliche Wissenschaft 35, Walter de Gruyter, Berlyn. https://doi.org/10.1515/9783110827149

Humphreys, C.J. \& Waddington, W.G., 1992, The Jewish calendar, a lunar eclipse and the date of Christ's crucifixion, Tyndale Bulletin 43(2), 331-351.

Jaubert, A.M., 1957, La date de la Cène: Calendrier biblique et liturgie chrétienne, Gabalda, Paris. https://doi.org/10.3406/ephe.1956.20279

Jaubert, A.M., 1965, The date of the Last Supper, transl. I. Rafferty, Society of St. Paul, New York.

Kenyon, G., 1941, The Chester Beatty Biblical Papyri, VIIII: Enoch and Melito, E Walker, London.

Knight, K., (ed.), 2003, The Catholic Encyclopedia. Elect. ed., viewed from www. newAdvent.org.

Leonhard, C., 2006, The Jewish Pesach and the origins of the Christian Easter, Walter de Gruyter, New York. https://doi.org/10.1515/9783110927818

Levine, B.A., 1989, The JPS Torah commentary: Leviticus, Jewish Publication Society, Philadelphia, PA.

Lieu, J., 1996, Image and reality: The Jews in the world of the Christians in the second century, Clark, Edinburgh.

Lohse, B., 1953, Das Passafest der Quartodezimaner in, Beiträge zur Förderung der Christelichen Theologie 2/54, C Bertelsmann, Gütersloh.

Mara, M.G., 1973, Évangile de Pierre, Cerf, Paris.

Mohrmann, C., 1962, 'Le conflit pascal au ॥e siècle. Note Philologique', Vigilae Christianae 16, 154-171. https://doi.org/10.1163/157007262X00181

Mosshammer, A.A., 2008, The Easter computus and the origins of the Christian era, Oxford University Press, Oxford. https://doi.org/10.1093/acprof:oso/ 9780199543120.001.0001

Perler, O., 1966, Méliton de Sardes: Sur la Pâque, Cerf, Paris.

Pretorius, W., 2006, 'Kulturele en teologiese lyne as die fondament van die vroegste Christendom', Acta Patristica et Byzantina 17, 272-294, Universiteit van SuidAfrika, Pretoria. https://doi.org/10.1080/10226486.2006.11745780

Pretorius, W., 2008, 'Bakens van die Ou Testamentiese kanonontwikkeling binne die eerste vyf eeue van die Christendom', Ongepubliseerde M.Th. verhandeling, Universiteit van Suid-Afrika.

Richard, M., 1965, 'La Lettre de Saint Irénée au Pape Victor', Zeitschrift für die neutestamentliche Wissenschaft und die Kunde der Älteren Kirche 56, 260-282. https://doi.org/10.1515/zntw.1965.56.3-4.260

Richardson, C.C., 1973, 'A new solution to the Quartodeciman riddle', Journal of Theological Studies 24, 74-83, Oxford University Press, Oxford. https://doi. org/10.1093/jts/XXIV.1.74

Roberts, A. \& Donaldson, J., 1997, Ante-Nicene Fathers, electr. edn., Logos Research Systems, Oak Harbor, WA.

Rouwhorst, L., 1989, Les Hymnes Pascales d'Ephrem de Nisibe. Analyse théologique et recherché sur l'évolution de la fête Pascale chrétienne à Nisibe et à Edesse et dans quelques Églises voisines au quatrième siècle 2 Vols, Brill, Leiden. https://doi. dans quelques Eglises voisines
$\mathrm{org} / 10.1163 / 9789004304215$ 
Rouwhorst, L., 2004, 'Liturgy on the authority of the apostles', Hilhorst 2004, 63-85. https://doi.org/10.1163/9789047404293_007

Rouwhorst, L., 2005. How eschatological was early Christian liturgy? Studia Patristica, Papers presented to the International Conference on Patristic studies, vol. 4 pp. 335-349, Berlin.

Rudolph, D., 2004, The Passover controversy in the East and West, Cambridge University, Unpublished.

Saulnier, S., 2012, Calendrical variations in Second Temple Judaism: New perspectives on the 'Date of the last Supper' debate, Brill, Leiden. https://doi. org/10.1163/9789004226326

Schürer, E., 1973-1987, The History of the Jewish People in the Age of Jesus Christ (175 $B C-A D$ 135), in rev. and ed. G. Vermes and F. G. B. Millar (with M. Black (vols. i-ii) and M. Goodman (vols. iii/1-2)), 3 vols. in 4 parts, T \& T Clark, Edinburgh.

Schürmann, H., 1951, 'Die Anfänge der christlichen Osterfeier',Theologische Quartalschrift 131, 414-425.

Souvay, C.L., 1929-1930, 'The Paschal controversy under Pope Victor I', Catholic Historical Quarterly 15(NS 9), 43-63.

Stemberger, G., 1991, 'Pharisäer, Sadduzäer, Essener: SBS 144', Katholiches Bibelwerk Stuttgart.

Stern, S., 2001, Calendar and community: A history of the Jewish calendar, second century BCE - tenth century CE, Oxford University Press, Oxford.

Stewart-Sykes, A., 1998, The Lamb's high feast. Melito, Peri Pascha and the Quartodeciman Paschal liturgy at Sardis, Brill, Boston, MA.

Strobel, A., 1977, Ursprung und Geschichte des frühchristlichen Osternkalenders, Texte und Untersuchengen zur Geschichte der altchristlichen literatur 121, Akademie, Berlin.
Strong, S., 1997, New Strong's dictionary of Hebrew and Greek words, Elect. edn. Logos Library System, Thomas Nelson, Nashville, TN.

Swanson, J., 1997, A dictionary of Biblical languages with semantic domains: Greek (New Testament. Elect. edn., Logos Library System, Logos Research Systems, Oak Harbor, WA.

Talmon, S., [1951] 1989, The World of Qumran from within: Collected Studies, Brill, Leiden.

Talmon, S., Ben-Dov, J. \& Glessmer, U., 2001, Qumran cave 4 XVI; Discoveries in the Judaean desert XXI, Clarendon press, Oxford.

Vaganay, L., 1930, L'Evangile de Pierre. Préface par le R.P.M.- J. Lagrange, 2iéme edn., Librairie Lecoffre, Paris.

Vanderkam, J.C., 1998, Calendars in the Dead Sea Scrolls: Measuring time: Literature of the Dead Sea Scrolls, Authoritative literature in the Dead Sea Scrolls, Dead Sea Discoveries 5(3), Routledge, London. https://doi.org/10.1163/156851798X00190

Vanderkam, J.C. \& Flint, P.W., 2004, The meaning of the Dead Sea Scrolls: Their significance for understanding the Bible, Judaism, Jesus, and Christianity, HarperSanFrancisco, San Francisco, CA.

Van der Watt, F. \& Tolmie, J., 2005, Apokriewe Ou en Nuwe Testament: Verlore boeke uit die Bybelse tyd, CUM, Vereeniging.

Van Goudoever, J., 1961, Biblical calendars, 2nd revised edn., Brill, Leiden.

Vermes, G., 2004, The complete Dead Sea Scrolls in English, 4th revised edn., Penguin Books, London.

Weitzel, K.L., 1848, Die christliche Passafeier der drei ersten Jahrhunderte. Zugleich ein Beitrag zur Geschichte des Urchristenthums und zur Evangelienkritik, Flammer \& Hoffman, Pforzheim.

Zernov, N., 1933, 'Eusebius and the Paschal controversy', Church Quarterly Review $116,24-41$ 